\title{
Experimental prediction of lead failure under tensile load using scanning contact potentiometry technique
}

\author{
A. A. Abu Ghazal ${ }^{\dagger, 1}$, Y. N. Husein², V.I. Surin ${ }^{3}$, S. A. R. Alkhdour ${ }^{4}$, G. H. Al-Malkawi ${ }^{4}$ \\ †gazal.ayman@yandex.ru
}
${ }^{1}$ Material Testing Laboratory, Research Laboratories and Information Directorate, Nuclear Sciences and their Applications sector, Jordan Atomic Energy Commission, Amman, 11934, Jordan
${ }^{2}$ Jordan Research and Training Reactor, Jordan Atomic Energy Commission, Ar Ramtha, 11934, Jordan
${ }^{3}$ Electrophysical Diagnostics and Non-destructive Testing Laboratory, Nuclear Physics and Technology Institute, National Research Nuclear University MEPhI, Moscow, 115409, Russia
${ }^{4}$ Nuclear engineering department, Jordan University of Science and Technology, Irbid, 22110, Jordan

The issue of accurate identifying in advance structural nonhomogeneities of metals is one of the main factors in improving the manufacturing efficiency and safety during service. This paper illustrates the conventional uni-axial tensile test that is carried out on the diffuse and localized necking stages of dog-bone shape lead specimen. The scanning contact potentiometry method was used to locate the rupture zone. Infrared radiation was used to heat the specimen up to $40^{\circ} \mathrm{C}$, in order to excite structural nonhomogeneities in the bulk of the tested specimen. It was found that the infrared radiation increases the predictable nonhomogeneity zone. A ductile rupture occurs in the same nonhomogeneity zone that was previously exactly identified using the scanning contact potentiometry method. The formed diffused necking was observed to initiate from the right where the rupture spread diagonally, at an angle of $70^{\circ}$ between the tensile axis and the rupture plane. However, the angle between the tensile axis and the hexagonal singular reflex plane was $69^{\circ}$, which was slightly different from the rupture angle. Both results of the rupture angles of the tensile test and the SCP are relatively matching and diverse from the theoretical calculations. The results shown in this work highlight the importance and the efficiency of the experimental SCP method in prediction of the material failure behaviour.

Keywords: ductile fracture, scanning contact potentiometry method, conventional tensile test.

УДК: 620.17

\section{Экспериментальное прогнозирование разрушения свинца под действием растягивающей нагрузки с использованием метода сканирующей контактной потенциометрии}

\author{
Абу Газал А. А. ${ }^{\dagger, 1}$ Хусейн Ю.Н. ${ }^{2}$, Сурин В.И. ${ }^{3}$, Альхдур С. А. Р. ${ }^{4}$, Аль-Малкави Г. Х. ${ }^{4}$ \\ ${ }^{1}$ Лаборатория испытаний материалов, Исследовательские лаборатории и Управление информации, Сектор ядерных \\ наук и их применений, Комиссия по атомной энергии Иордании, Амман, 11934, Иордания \\ ${ }^{2}$ Иорданский исследовательский и учебный реактор, Комиссия по атомной энергии Иордании, \\ Ар Рамта, 11934, Иордания \\ ${ }^{3}$ Лаборатория функциональной электрофизической диагностики и неразрушающего контроля, Институт ядерной \\ физики и технологий, Национальный исследовательский ядерный университет МИФИ, Москва, 115409, Россия \\ ${ }^{4}$ Факультет ядерной инженерии, Иорданский университет науки и технологий, Ирбид, 22110, Иордания
}

Проблема точного заблаговременного выявления структурных неоднородностей металлов является одним из основных факторов повышения эффективности производства и безопасности в процессе эксплуатации. В данной статье продемонстрировано обычное испытание на одноосное растяжение, которое проводится на этапах диффузного и локализованного образования шейки гантелевидного образца свинца. Для определения зоны разрыва использовался метод сканирующей контактной потенциометрии (СКП). Инфракрасное излучение использовалось для нагрева образца до $40^{\circ} \mathrm{C}$ с целью возникновения структурных неоднородностей в объеме исследуемого образца. 
Было обнаружено, что инфракрасное излучение увеличивает площадь прогнозируемой зоны неоднородности. Пластичный разрыв происходит в той жезоне неоднородности, которая ранеебыла точно идентифицирована методом сканирующей контактной потенциометрии. Наблюдалось, что образовавшаяся диффузная шейка начинается справа, где разрыв распространяется по диагонали, под углом $70^{\circ}$ между осью растяжения и плоскостью разрыва. Однако угол между осью растяжения и гексагональной сингулярной плоскостью рефлекса составлял $69^{\circ}$, что немного отличалось от угла разрыва. Оба результата по углам разрыва при испытании на растяжение и СКП относительно совпадают и отличаются от теоретических расчетов. Результаты, показанные в этой работе, подчеркивают важность и эффективность экспериментального метода СКП в прогнозировании поведения материала при разрушении.

Ключевые слова: вязкое разрушение, метод сканирующей контактной потенциометрии, традиционные испытания на растяжение.

\section{Introduction}

When the applied stress is greater than the normal tensile strength of the material, a ductile fracture occurs, resulting in failure after plastic deformation [1]. Usually, the material will fail in a ductile manner when plastically deformed, where the cross section is continuously reduced and can no longer withstand the applied load resulting in a ductile failure, where there is substantial distortion or plastic deformation of the failed region [2]. The dauctile fracture of a metallic material is significantly influenced by many factors making it a very complicated phenomenon. These factors include the state of the material, its geometry, strain path, temperature and the strain rate [3]. The presence of any non-homogeneity within the microstructure of the material leads to the concentration of strain and, thus, to an increase in the extent of deformation up to the stage where it undergoes necking and fails [4]. The residual stress is concentrated in the region defects causing easier destruction around the vacancy [5]. The residual stresses are dependent on the factors including heat treatment applied, in addition to the intensity and nature of the residual stresses originally within the body [6]. Scanning contact potentiometry (SCP) is a new non-destructive material testing method making it possible to assess the microstructure of the object material without affecting or damaging it. The SCP technique opens up the possibility of real-time NDT of surface for stress and strain, plastic deformation mechanisms, stages of internal defects initiation to the point of material failure $[7,8]$. The SCP physical principle relies on measuring electrical potentials on the surface of the material under study, an increasing dynamic load applied would cause plastic deformation and produce a wave that travels at the elastic speed $[9,10]$. As defects and cracks grow within metals, they initiate stress waves $[11,12]$ that travel to the surface and lead to an increase in the real contact area due to the increase in the number of contact spots between the material surface and the sensor (transducer of SCP method), consequently leading to the change in the detected contact potential difference between the sensor and the sample (the surface of the studied material). The greater the number and area of contact spots between two metal surfaces, the higher the probability of electrons overcoming the dipole barrier. Changes in the number and area of contact spots causes a change in the structural defects formed within the volume of the material and the emission of mechanical stress waves creating reflexes, which are an illustration of the distribution of the detected surface potentials on potentiograms. The process of SCP testing includes surface electrical reflexes being investigated under the impact of external and internal factors where the laws of solid state deformation are used to explain the distribution obtained on potentiograms at high Structural levels of signal (SLS). According to the phenomenon of contact potentiometry, at high structural levels, reflexes from microscopic inhomogeneities are demonstrated on potentiograms. The formation of an inhomogeneous surface deformation causes changes in the local work function and the conductivity of the contacting surfaces resulting in an increase in the amplitude of the electrical signal. The SCP method have been used in tracking the martensitic formation in austenitic stainless steel in many joint experiments at IBR-2 research nuclear reactor in the Joint Institute for Nuclear Research (JINR) and results obtained were verified using thermal neutron diffraction method [13-15]. Furthermore, the SCP method was used to study early formation and growth of embryonic fatigue cracks in metals [16]. A variety of research projects were conducted to study the performance of material such as lead-bismuth or lead to design a model for a real spallation target, the performance of neutronics, reactor physics and thermal hydraulics [17]. Lead offers useful properties such as good corrosion resistance, malleability, energy absorption and electrical conductivity. Some applications of lead sheets are bonding it to steel for chemical tank linings, noise and radiation shielding or as a lining for chemical or nuclear facility piping [18]. Slant ductile rupture is one of the common failure modes at the pressure vessel and piping industry, which can be due to excessive internal pressure and/or axial loading. Understanding the physics of ductile rupture is important for predicting the fracture modes and the crack propagation path for ductile metals. The Slant fracture behavior have been analytically studied by using the advanced damage plasticity theory [19]. Rapidly changing the applied external load for a short time period can produce an effect, which shall be considered from the stress wave motion point of view [20]. By its nature, the heat is accompanying with the infrared radiation, therefore absorption of infrared radiation is all the time followed by the generation of heat. In details, the motion and kinetic energy of molecules are the main source of heat within the material, molecules absorb infrared radiation and ultimately convert it to heat. The main goal of this qualitative work is to focus on the powerful capabilities of the SCP method as a non-destructive material testing technique, which includes the study of the material behaviour at multiple scales ranging from the microscopic up to macroscopic levels. The obtained results in this work 
are assumed to be important as there exists a scarce literature on the subject, in particular, of predicting exactly the ductile failure zone for lead in addition to predicting the material breakdown, which is a fundamental issue that contributes to increasing the safety of personnel and reliability of equipment within all industrial fields.

\section{Methodology}

Using the SCP method, a study has been performed on a flat lead specimen with gauge dimensions of $89.5 \times 13.00 \times 2.00 \mathrm{~mm}$. In order to excite the structural nonhomogeneities within the tested volume, a Tungsram $230 \mathrm{~V}$ IR lamp was used to heat the specimen up to $40^{\circ} \mathrm{C}$, then after natural cooling under ambient condition the SCP applied again. After that a tensile test undergoes until the tlocalization of necking and the appearance of rupturing zones. As presented in Fig. S1b (Supplementary Material), the testing speed was $0.5 \mathrm{~mm} / \mathrm{min}$ and the universal testing machine is $\mathrm{H} 50 \mathrm{KS}$. Using SCP's semi-automated scanner device in 10 horizontal measuring tracks before conducting the tensile test has the major advantage in identifying the non-homogenous regions in the specimen. Fig. S1a (Supplementary Material) shows that the distance between adjacent tracks is less than $1 \mathrm{~mm}$. The used transducers are needle type and are made up from nickel and high carbon steel, it is worth to mention that the needle type transducer has a diameter of $\varnothing 2.00 \mathrm{~mm}$ and the nickel part of it has the property of corrosion resistant with a sensitivity of $0.01 \mu \mathrm{V}$. During testing, the fixed transducer is connected to the shoulder of specimen outside the gauge area, while the movable transducer has a scan speed of $0.3 \mathrm{~mm} / \mathrm{sec}$. The entire process of collecting and recording the data is performed automatically. Digitization of the electrical signal takes place at a sampling rate of $1 \mathrm{~Hz}$, while saving these signals is performed by using a special measuring information system equipped with a programmable amplitude discriminator (discrimination range $40 \mathrm{~dB}$ ). This discriminator assists in cutting off the signals above the already assigned threshold, which can help in the study of different Structural levels of Signal (SLS).
Windows operating system is used to control the diagnostic system, which consists of hardware and software complexes, while the schematic diagram of the experimental setup used during adapting the SCP method is shown in Fig. S1c (Supplementary Material).

\section{Results and discussion}

With the help of potentiograms, the results of applying the SCP method to the tested Lead specimen are presented visually through showing the distribution of the electrical potential difference reflexes across the specimen surface gauge area. The hexagonal singular reflexes are located near the right edge of the specimen, meanwhile other reflexes are also located in the center of the specimen close to the left edge, and all these reflexes are positioned side by side in a vertical alignment as shown in Fig. 1a. In the same zone, all these reflexes trend to appear frequently at all SLS above the SLS $=1$.

After heating up the specimen by exposing it to IR light and then leaving it to cooling down under ambient room temperature, the following can be recognized from the results shownin Fig. 1b: Firstly, the nonhomogeneous zone increased in the tested areas after heating. Secondly, the appearance of a right hexagonal singular reflex at high $\mathrm{SLS}=4.721$, and longitudinal zone that extends vertically from the bottom right fillet and ends at the same place where the hexagonal singular reflex is located. As previously mentioned, the reflexes trend to appear frequently at $\mathrm{SLS}=3, \mathrm{SLS}=4$, SLS $=4.523$ and SLS $=4.721$, where, especially at SLS $=4.721$ the fusion of reflexes can be noticed to be longitudinally located in the center close to left edge.

The term "reflex" as used herein and relating to the SCP method refers to single or multiple microscopic structural inhomogeneities that exist within the volume of the specimen under testing. Consequently, the tested Lead specimen, whether using the SCP testing method under ambient conditions or following heating-cooling process using IR light, contains a structural inhomogeneity zone as illustrated in Fig. 1a, b. It can be noticed that the nonhomogeneous zone increased in area after heating.

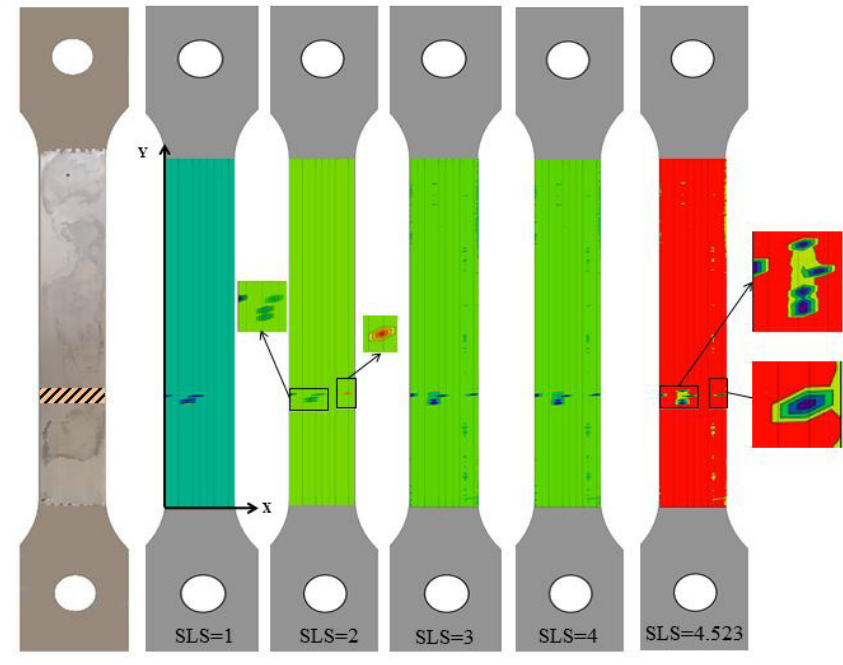

a

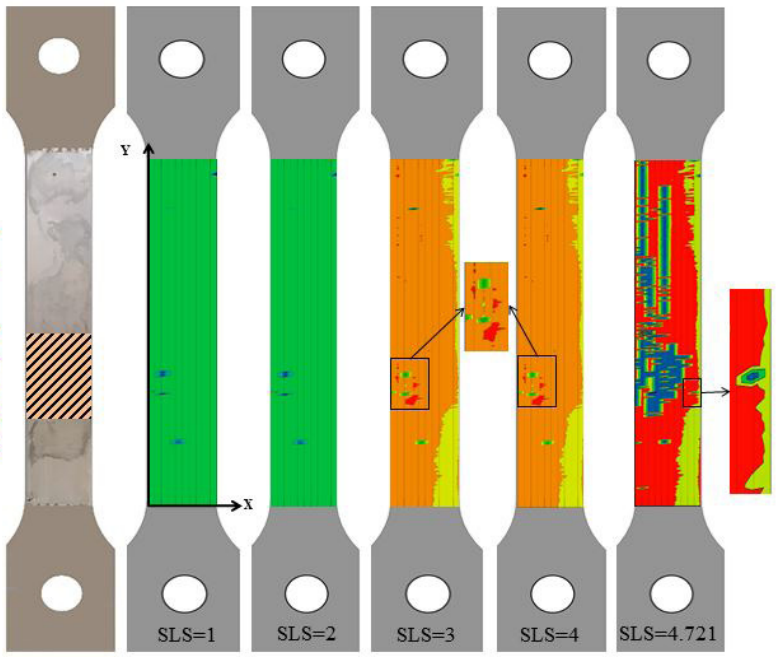

$\mathrm{b}$

Fig. 1. (Color online) The real image of the studied specimen gauge area includes the area of inhomogeneity indicated by diagonal lines identified according to SCP potentiograms at various SLS under ambient conditions (a), after exposure to IR light (b). 
After applying an uniaxial tensile testing, a rapture appears within the nonhomogeneous zone at the same region where the SCP testing method is formerly applied and have the maximum reflexes as demonstrated in Fig. $2 \mathrm{~d}$. When the load reached $F \approx 320 \mathrm{~N}$ and a clear rupture area obviously appeared, at that point the tensile testing stopped, in order to not destroy the specimen. Momentarily and after the removal of the specimen from the tensile machine, an image of the specimen has been taken. This image shows that the rupture extended diagonally starting from the right edge as illustrated in Fig. 2 d,f. As shown in Fig. 2 e and f, and as results of the SCP potentiogram and tensile testing, the values of fracture angles between tensile axis and rupture plane and the angle between tensile axis and hexagonal singular reflex plane are $69^{\circ}$ and $70^{\circ}$, respectively. Comparing our results with the theoretical calculations $\left(\mathrm{Schmid} \approx 45^{\circ}\right.$, Hill $\approx 54^{\circ}$ ), some diversity can be recognized here. The reason of such consistency between the theoretical and experimental results attributed to the microstructural characteristics and preliminary deformation $[21,22]$. Moreover, the final fracture angle between the fracture plane and the tensile axis is always larger than theoretical value as stated in [23]. It was noticed that the area of diffused necking from the left edge was wider than the right edge due to diagonally propagation with increasing deformation. Therefore, the deformation is significantly concentrated on the right side because of the presence of single zone of inhomogeneity that was able to dominate the initiation of the rupture process. As demonstrated in Fig. 2 e, the left edge of the specimen also subjected to broadly concentration of deformation due to distribution of stress there which caused wide diffused necking area that is not localized at specific point. It is known that stress concentration factor $\alpha_{\sigma}$ increases with the decrease of the curvature diameter $d$ in the inhomogeneity zone side. The extremity of the stress concentration depends on the geometry of the inhomogeneity zone structure, usually indicated to as the shape of the zone. If the specimen was exposed to homogeneous stress distribution, the hole (inhomogeneity zone) will cause an inhomogeneous stress distribution in the sensitive section, which is the minimum section at the hole [24].

\section{Conclusion}

In this work, predicting the failure for a Lead specimen was investigated using the SCP method. It was observed that the last stage of the performed uniaxial tensile test on the specimen caused a diffused, localized necking and the initiation of a ductile rupture at the same non-homogeneous zone that was formerly identified precisely using SCP. Potentiograms showed that the intensity of the signals of the electrical potential difference in the form of reflexes is focused on the instable structural zone within the bulk of the studied specimen. The tested specimen were also exposed to IR light and then left to cool naturally, which attributed to the excitation of any structural non-homogeneities present within the studied specimen bulk. Consequently, the test sensitivity and measurements efficiency increased, which reflected in the apparent increase in area of the predicted structural nonhomogeneity zone. The diffused necking formation was observed to be initiated from the right of the specimen where the rupture spread diagonally, at an angle of $70^{\circ}$ between tensile axis and rupture plane. However, the angle between the tensile axis and the hexagonal singular reflex plane was $69^{\circ}$ which was slightly different from the rupture angle. Both results of rupture angles of tensile test and SCP are relatively matching and diverse from the theoretical calculations in an explainable matter. The results shown in this work highlight the importance and the efficiency of the experimental SCP method in precisely predicting the material failure locations before it takes place.

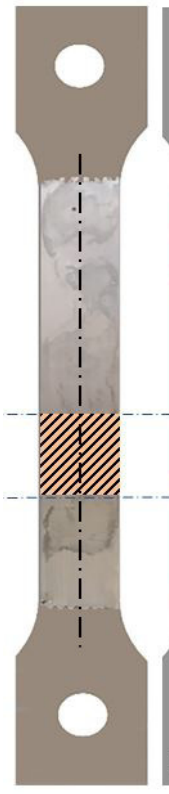

a

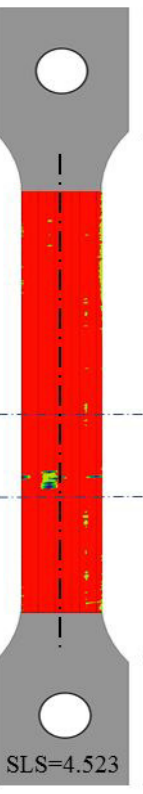

b

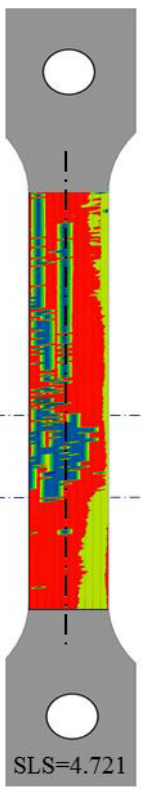

C

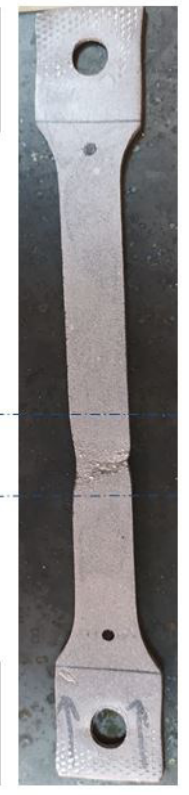

d
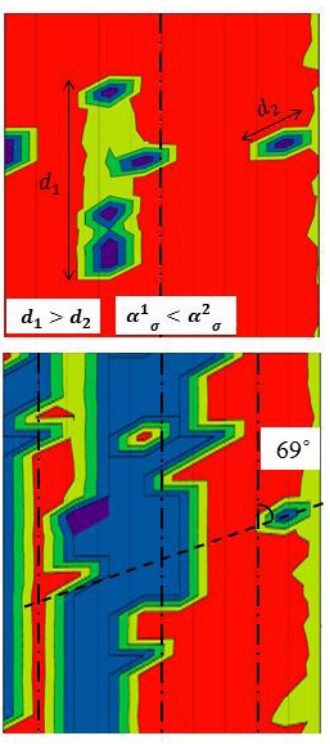

$\mathrm{e}$

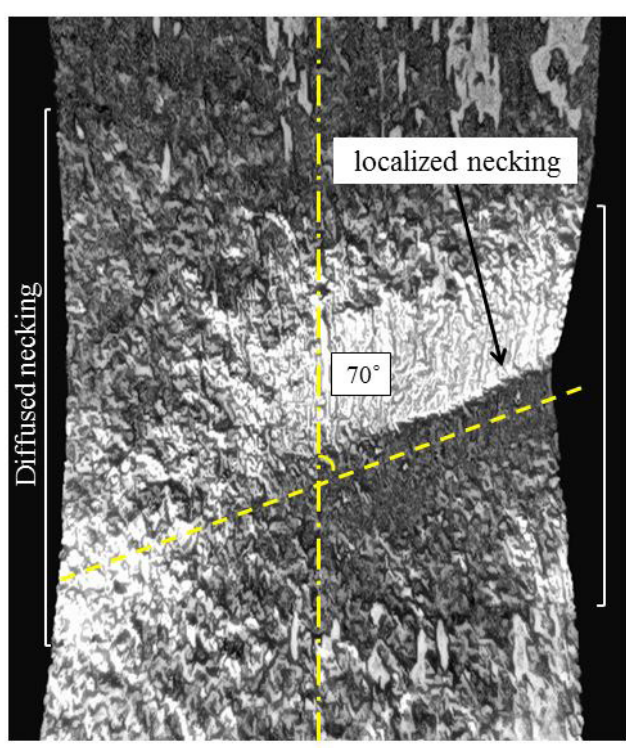

$\mathrm{f}$

Fig. 2. (Color online) Image of a Lead specimen before tensile testing and a zone of inhomogeneity is indicated by diagonal lines (a), SCP potentiograms at SLS $=4.523$ (b), SCP potentiograms at SLS $=4.721$ after IR heating (c), a real image of a Lead specimen after tensile testing, consisting of a rupture with the inhomogeneity zone formally detected by the SCP method (d), SCP potentiogram of the inhomogeneity zone at SLS $=4.523$ and 4.721, respectively (e), a real image of the rupture zone after finishing tensile test (f). 
Supplementary material. The online version of this paper contains supplementary material available free of charge at the journal's Web site (lettersonmaterials.com).

Acknowledgments. The authors appreciate the support provided by the Russian Foundation for Basic Research (RFBR) [grant number 19-08-00266/20, 25.03.2020]. Authors also acknowledge the Heads of the Jordan Atomic Energy Commission, Jordan University of Science and Technology, and the National Research Nuclear University MEPhI for their continuous support and cooperation in applied scientific research without limits or obstacles.

\section{References}

1. S.A. Rackley. 23 - Carbon dioxide transportation, Carbon Capture and Storage (2nd Edition). ButterworthHeinemann (2017) pp. 595-611. Crossref

2. P.R. Lewis. Chapter 2 - Sample Examination and Analysis. In: Woodhead Publishing in Materials, Forensic Polymer Engineering (2nd Edition). Woodhead Publishing (2016) pp. 33 - 69. Crossref

3. H. Li, M. Fu. Chapter 3 - Damage Evolution and Ductile Fracture. In: Deformation-Based Processing of Materials. Elsevier (2019) pp. 85-136. Crossref

4. F.P.E. Dunne. International Journal of Plasticity. 14 (4-5), 413 (1998). Crossref

5. V.T. Pham, T. H. Fang. Sci Rep. 10, 15082 (2020). Crossref

6. F. O. Neves, T. L. L. Oliviera, D. U. Braga, A.S. Chaves da Silva. Advances in Materials Science and Engineering. 2014, 658679 (2014). Crossref

7. A.A. Abu Ghazal, P.S. Dzhumaev, A.V. Osintsev, V.I. Polsky, V.I. Surin. Lett. Mater. 9(1), 33 (2019). (in Russian) [А. А. Абу Газал, П. С. Джумаев, А. В. Осинцев, В.И. Польский, В.И. Сурин. Письма о материалах. 9(1), 33 (2019). Crossref

8. V. I. Surin, A. I. Alwaheba, V. G. Beketov, A. A. Abu Gazal. J. Phys.: Conf. Ser. 1636, 012017 (2020). Crossref

9. J.F. Bell. Propagation of plastic waves in pre-stressed bars. Technical Report No. 5, U.S. Naval Contract. The Johns Hopkins University. June 1951.

10. E. J. Sternglass, D. A. Stuart. J. Appl. Mech. 20 (3), 427 (1953). $\underline{\text { Crossref }}$
11. V.E. Panin, V.S. Pleshanov, S. A. Kobzeva, S.P. Burkova. Theor. Appl. Fract. Mech. 29 (2), 99 (1998). Crossref

12. L. B. Zuev, V. I. Danilov. Phys. Solid State. 39, 1241 (1997). Crossref

13. A.A. Abu Ghazal, V.I. Surin, G.D. Bokuchava, I. V. Papushkin. International conference Condensed Matter Research at the IBR-2. Joint Institute for Nuclear Research, Dubna, Russia (2020) p. 115. Crossref

14. A.A. Abu Ghazal, V.I. Surin, G.D. Bokuchava, I.V. Papushkin. Journal automation in industry. 3, 61 (2019). (in Russian) [А.А. Абу Газал, Г.Д. Бокучава, И.В. Папушкин, В.И. Сурин. Автоматизация в промышленности. 3, 61 (2019).] Crossref

15. A. A. Abu Ghazal, G.D. Bokuchava, I.V. Papushkin, V.I. Surin, E. A. Shef. XIII International Youth Scientific and Practical Conference "future of atomic energy AtomFuture 2017”, KnE Engineering. Obninsk, Kaluga region, Russia (2017) p. 109. Crossref

16. V.I. Surin, V.I. Polskij, A.V. Osintsev, P.S. Dzhumaev. Russ J Nondestruct Test. 55, 59 (2019). Crossref

17. K. Kikuchi. 5.09 - Material Performance in Lead and Lead-bismuth Alloy (ed. by Rudy J.M. Konings). In: Comprehensive Nuclear Materials. Elsevier (2012) pp. 207-219. Crossref

18. J.F. Smith. Lead Alloys: Alloying, Properties, and Applications. Encyclopedia of Materials: Science and Technology. Elsevier (2001) pp. 4434-4438. Crossref

19. H. Huang, L.Xue. International Journal of Pressure Vessels and Piping. 86 (5), 319 (2009). Crossref

20. Y. M. Haddad. Elastic Wave Propagation. In: Mechanical Behaviour of Engineering Materials. Springer, Dordrecht (2000) p. 82. Crossref

21. F. Gramazio, M. Kohler, S. Langenberg. Fabricate 2014: negotiating design and making. UCL Press, Architecture (2017) p. 168.

22. D.F. McFarland. A Preliminary Study of the Alloys of Chromium, Copper, and Nickel. Forgotten Books (2012) p. 70.

23. C. Li, E. Daxin, N. Yi. Journal of Materials Research, 31 (24), 3991 (2016). Crossref

24. Stress Concentration at Notches. In: Fatigue of Structures and Materials (ed. by J. Schijve). Springer, Dordrecht (2009) pp. 59-88. $\underline{\text { Crossref }}$ 